\title{
Correction to: Resilin matrix distribution, variability and function in Drosophila
}

Steven Lerch ${ }^{1,2,3}$, Renata Zuber ${ }^{1}$, Nicole Gehring ${ }^{2}$, Yiwen Wang ${ }^{2}$, Barbara Eckel ${ }^{1}$, Klaus-Dieter Klass ${ }^{3}$, Fritz-Olaf Lehmann ${ }^{4}$ and Bernard Moussian ${ }^{1,2,5^{*}}$

Correction to: BMC Biol 18, 195 (2020)

https://doi.org/10.1186/s12915-020-00902-4

Following publication of the original article [1], an error was identified in reference 23. It should have been presented as: Rice MJ. Function of resilin in tsetse fly feeding mechanism. Nature. 1970;228(5278):1337-8.

The original article [1] has been corrected.

\section{Author details}

${ }^{1}$ Applied Zoology, Technical University of Dresden, Dresden, Germany.

${ }^{2}$ Animal Genetics, Interfaculty Institute of Cell Biology, University of Tübingen, Tübingen, Germany. ${ }^{3}$ Senckenberg Natural History Collections, Dresden, Germany. ${ }^{4}$ Animal Physiology, University of Rostock, Rostock, Germany. ${ }^{5} \mathrm{CNRS}$, Inserm Institute of Biology Valrose, Université Côte d'Azur, Nice, France.

Published online: 30 July 2021

\section{Reference}

1. Lerch $\mathrm{S}$, et al. Resilin matrix distribution, variability and function in Drosophila. BMC Biol. 2020;18:195. https://doi.org/10.1186/s12915-02000902-4.

The original article can be found online at https://doi.org/10.1186/s12915020-00902-4

* Correspondence: bernard.moussian@unice.fr

${ }^{1}$ Applied Zoology, Technical University of Dresden, Dresden, Germany

${ }^{2}$ Animal Genetics, Interfaculty Institute of Cell Biology, University of Tübingen, Tübingen, Germany

Full list of author information is available at the end of the article
Ready to submit your research? Choose BMC and benefit from:

- fast, convenient online submission

- thorough peer review by experienced researchers in your field

- rapid publication on acceptance

- support for research data, including large and complex data types

- gold Open Access which fosters wider collaboration and increased citations

- maximum visibility for your research: over 100M website views per year

At BMC, research is always in progress.

Learn more biomedcentral.com/submissions

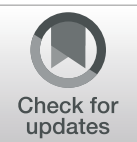

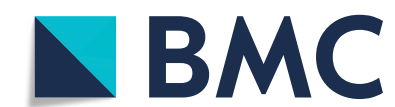

(c) The Author(s). 2021 Open Access This article is licensed under a Creative Commons Attribution 4.0 International License, which permits use, sharing, adaptation, distribution and reproduction in any medium or format, as long as you give appropriate credit to the original author(s) and the source, provide a link to the Creative Commons licence, and indicate if changes were made. The images or other third party material in this article are included in the article's Creative Commons licence, unless indicated otherwise in a credit line to the material. If material is not included in the article's Creative Commons licence and your intended use is not permitted by statutory regulation or exceeds the permitted use, you will need to obtain permission directly from the copyright holder. To view a copy of this licence, visit http://creativecommons.org/licenses/by/4.0/. The Creative Commons Public Domain Dedication waiver (http://creativecommons.org/publicdomain/zero/1.0/) applies to the data made available in this article, unless otherwise stated in a credit line to the data. 